\title{
GENDER, RESISTANCE, AND CONFORMITY IN EARLY MODERN SCOTLAND, 1560-1650
}

\author{
Ryan Burns, Northwestern University
}

ABSTRACT

This article claims that men and women in mixed marriages often subverted patriarchal norms when attempting to escape ecclesiastical censure in early modern Scotland. Ministers held husbands responsible for ensuring the conformity of their households, and they insisted that Protestant husbands bring their wives into the fold. These husbands then argued that they had no right to compel their wives in matters of conscience. Some even insisted that they had no control over their wives whatsoever. They were willing to appear failing in their patriarchal duties in order to protect their wives from the kirk, which was loath to interfere much further in marital relationships. Married women risked excommunication for their defiance, but local authorities were unable to confiscate any of their assets, which were held in trust by their husbands. Catholic women thus used the patriarchal assumptions of religious authorities as a means of undermining religious conformity.

Keywords: Scotland; religious history; women; marriage; $16^{\text {th }}$ century; $17^{\text {th }}$ century; power; authority; social control

In December 1600, the presbytery of Aberdeen decided to settle a matter that had long troubled them. John Leslie, the 
laird of Wardes, had not only failed to attend sermons at his parish kirk in Dyce; he had also ignored repeated summons to appear before his local kirk session, the committee of parish elders tasked with enforcing discipline. The presbyters, suspecting him to be a Catholic, threatened Leslie with excommunication if he refused another call, and they duly ordered him to appear on 2 January 1601. This time he came. He seemed remorseful for his absence from church, and he pleaded that he no longer considered himself to be a Catholic. He meekly "offereit to satisfie the kirkis desire in all thingis," agreeing "nocht onlie to subscryve, bot to sweir to the religioun" presently professed in Scotland. ${ }^{1}$ The presbyters ordered Leslie to formally subscribe to the Scots Confession of Faith on 6 February, and they hoped that he would not do so alone. Leslie's Catholic wife, Elspeth Gordon, had not accompanied her husband to the presbytery that day, but the presbyters were determined to win her conversion as well. Unfortunately, when they asked Leslie whether "he wald causs his ladie be present with him, and to be partaker with him, and to subscryve as he did," the would-be convert answered that he would not. He cloaked his refusal in high-minded language, reminding the presbytery that "in thingis concerning hir saull and conscience, he had na powar to command her". ${ }^{2}$ He offered to speak with her about the possibility of converting, but pointedly left any further prodding to the presbyters themselves. If she would not comply, Leslie added, "let the ministeris deal with her utherwayes according to the discipline of the kirk". 3

John Leslie and Elspeth Gordon were effectively exploiting a gendered loophole. They relied on the patriarchal

${ }^{1}$ J. Stuart, ed., Selections from the Records of the Kirk Session, Presbytery, and Synod of Aberdeen (Edinburgh: Spalding Club, 1846), 173.

${ }^{2}$ Ibid.

${ }^{3}$ Ibid. 
assumptions embedded in Scottish custom, which offered husbands considerable authority over their wives, to shield recusant wives from any prosecution for nonconformity. Elspeth Gordon's status as a married woman offered some protection from the harsher penalties that would have accompanied excommunication, despite the manifold summons that she received. The state could not confiscate any of her property, which was formally administered by her husband, nor could it fully cordon her off from other Protestants in her community. Ministers held husbands responsible for ensuring the conformity of their households, and they insisted that Protestant husbands bring their Catholic wives into the fold. These husbands then argued that they had no right to compel their wives in matters of conscience. Some even insisted that they had no control over their wives whatsoever. They were willing to appear to be failing in their patriarchal duties in order to protect their wives from the kirk, which was loath to interfere much further in marital relationships. Catholic women thus used the patriarchal assumptions of religious and secular authorities as a means of undermining religious conformity.

Above all, Catholic women in mixed marriages relied on the inherent protections such unions afforded them. The very existence of mixed marriages challenged the confessional order in church and state, raising awkward questions about apostacy, conformity and the education of one's children. Nevertheless, Biblical injunctions on the inviolability of marriage significantly circumscribed the kirk's ability to intervene, at least once the marriage had been solemnized. ${ }^{4}$

\footnotetext{
${ }^{4}$ While kirk sessions sometimes prohibited couples from marrying, usually on account of age, religious ignorance (ministers required each couple to demonstrate their mastery of the Lord's Prayer or the Apostles Creed before banns could be published), or consanguinity, they routinely dismissed familial objections to prospective marriages. The First Book of Discipline insisted that fathers had no right to veto their daughters' choice
} 
Kirk sessions forcibly separated couples married after 1560 by a Catholic priest, compelling husband and wife to live apart until they were married according to Protestant rites, but any marriage celebrated by a minister was recognized as valid in Scottish law. ${ }^{5}$ The General Assembly forbade ministers from performing mixed marriages, censuring or dismissing those who did so, but many couples prudently declined to advertise their religious differences until after the marriage was performed. And while some relationships between Protestants and Catholics were genuinely mixed, a partnership between two believers of different faiths, many "mixed" marriages in early modern Scotland were between covertly Catholic men and overtly Catholic women. The husband's conformity safeguarded the family's standing and inheritance, which enabled the wife to preserve the family's beliefs and pass them on to the next generation.

Such arrangements were common among religious minorities in early modern Europe. Historians of England and elsewhere have increasingly turned to mixed marriages, probing the practical limitations on confessional uniformity. John Bossy, Alex Walsham and Michael Questier have demonstrated that English women in mixed marriages enjoyed a wide latitude to practise their underground faith, the product of legal loopholes and official reticence to interfere in domestic affairs. ${ }^{6}$ Local authorities were unable to impose recusancy

of husband (so long as that husband was sufficiently godly) on the grounds that "the work of God ought not to be hyndered by the corrupt affectionis of worldlie men". See, for example, David Laing, ed. The Works of John Knox, 6 vols. (Edinburgh: Bannatyne Club, 1846-64), 2:246; Margo Todd, The Culture of Protestantism in Early Modern Scotland (New Haven, CT: Yale University Press, 2002), 267.

${ }^{5}$ For an example of forcible separation, see: Synod of Moray Minutes, 1668-1686, CH2/271/3, 31, National Records of Scotland [hereafter NRS], Edinburgh, UK.

${ }^{6}$ Alexandra Walsham, Church Papists: Catholicism, Conformity and Confessional Polemic in Early Modern England (Woodbridge: Boydell 
fines directly on married women, who were classified in English common law as "femmes covert," with property vested in their husbands. And while a 1606 statute permitted the dismissal of officeholders with recusant wives, on the grounds that such men were likely secret Catholics themselves, local JPs were generally reluctant to levy any further penalties on married couples. ${ }^{7}$ Matters were even more lax elsewhere in Protestant Europe. In the Netherlands, where a handful of parish elders and even ministers were reputed to have Catholic wives, the authorities in church and state showed little reticence in accepting the validity of mixed marriages. As Ben Kaplan notes in his Divided by Faith: Religious Conflict and the Practice of Toleration in Early Modern Europe, mixed couples were permitted to marry in the Dutch Reformed Church, so long as the Catholic partners promised not to interfere in the Protestant faith of their spouse and the Protestant education of their children. If a Protestant service offended the sensibilities of the Catholic partner, the couple could even opt for a civil ceremony performed by the local magistrate. ${ }^{8}$

In Scotland, however, there was no question of having a civil marriage ceremony in lieu of a Protestant service. Catholic women in mixed marriages did indeed possess certain privileges, but the overreliance of many historians on civil evidence can obscure the very real pressures such women faced. Scholars have traditionally approached Catholicism in Scotland by analyzing the country's penal laws and their rather

Press, 1999). See also Michael Questier, Catholicism and Community in Early Modern England: Politics, Aristocratic Patronage and Religion, 1550-1640 (Cambridge: Cambridge University Press, 2006).

${ }^{7}$ Walsham, Church Papists, 80.

${ }^{8}$ Benjamin Kaplan, Divided by Faith: Religious Conflict and the Practice of Toleration in Early Modern Europe (Cambridge, MA: Belknap Press, 2007), 277-83. 
lax enforcement. ${ }^{9}$ Secular authorities did not levy punitive fines on conforming men for having recusant wives, and they refrained from imposing any restrictions on officeholding as well. Yet the nation's campaign to suppress Catholicism was directed not by the state, but by the kirk, which had absolutely no compunction on summoning women who hailed from mixed marriages, even if it could not punish them in exactly the same way. When Alastair Roberts explored these issues in his 1991 article "The Role of Women in Scottish Catholic Survival," his focus on secular persecution led him to underestimate the pressures that Catholic women faced from zealous kirk sessions. Relying in part on conclusions drawn from mixed marriages in England, whose interplay with the state he assumed to be broadly similar to the situation prevailing in Scotland, Roberts argued that the Scottish government had little interest in the conformity of recusant women. According to Roberts, as long as a couple committed to raising their children as Protestants, much like the concessions offered to mixed couples in the Netherlands, Scottish authorities generally looked the other way if a wife worshiped as a Catholic. Roberts pointed to the examples of Jean Gordon, Countess of Sutherland, and Henrietta Stewart, Marchioness of Huntly, whom James VI actually permitted to hear mass so long as the priest was not a Jesuit. ${ }^{10}$

When clerical authorities are considered alongside secular ones, it becomes clear that Scottish Catholic women were not granted as much latitude as historians have suggested. Dispensations of the sort granted to the Countess of Sutherland and the Marchioness of Huntly were vanishingly rare, even among the very elite. The king demurred when Margaret Seton,

\footnotetext{
${ }^{9}$ See for example: Allan Macinnes, "Catholic Recusancy and the Penal Laws, 1603-1707," Records of the Scottish Church History Society, 23 (1987): 27-63.

${ }^{10}$ Alastair Roberts, "The Role of Women in Scottish Catholic Survival," The Scottish Historical Review 70, no. 2 (Oct. 1991): 132.
} 
Lady Paisley, asked for similar privileges in 1610, offering no support to the aged noblewoman when the kirk demanded her conformity. She was married, but her husband had apparently gone insane, and was therefore deemed incapable of ensuring the godliness of his household. ${ }^{11}$ Seton penned a moving letter asking for help, forlornly hoping that "his Majesty, who hath always had a gracious regard to me and mine, will not think me unworthy in my extreme of sickness". ${ }^{12}$ James was unmoved, and her letter plainly reveals the rigour by which the kirk, if not the state, sought total religious uniformity. Seton discussed her illness at length, complaining that "these four years past I have been subject a vehement payne, arising from distillations and humours in my head, with a continual toothache, giving me [such] torment as scarce I have half-an-hour's release by night or by day". She lamented that these torments provided no respite from a determined kirk, since "to aggravate my payne, I am summoned by the Church to confer and attend on the Presbyteries and other dyets". ${ }^{13}$ The kirk clearly had no sympathy for her pleas of sickness, whatever her temporal rank.

Scholars are beginning to appreciate the importance of ecclesiastical sanctions in securing religious uniformity in Scotland. Margo Todd and Michael Graham have incorporated cases against Catholics into their wider studies on kirk discipline, while Paul Goatman and Dan MacLeod have engaged with kirk session minutes for their studies on Catholics in Glasgow. ${ }^{14}$ Catherine McMillan recently examined

${ }^{11}$ Peter Holmes, "Hamilton, Claud, first Lord Paisley (1546?-1621)," Oxford Dictionary of National Biography, Oxford University Press, 2004. 12 "Dame Margaret Seton, Lady Paisley to the Queen's Majesty, 1 September 1610", in Original Letters Relating to the Ecclesiastical Affairs of Scotland: 1603-1614, ed. David Laing (Edinburgh: Bannatyne Club, 1851), 257.

${ }^{13}$ Ibid.

${ }^{14}$ Michael Graham, The Uses of Reform "Godly Discipline" and Popular Behavior in Scotland and Beyond (Leiden; Brill, 1996). For urban histories, see Michael Lynch, Edinburgh and the Reformation (Edinburgh: 
ecclesiastical efforts to secure the conformity of Catholic women in the northeast, noting the tenacity with which kirk sessions pursued even high-born women. ${ }^{15}$ Nevertheless, McMillan's conclusion that ministers pursued men and women with equal vigour leaves unresolved the question of how certain women, married or not, managed to deflect unwanted attention, apart perhaps from individual courage. ${ }^{16}$ Married women were not without protection if they sought to defy the kirk, but this did not stem from reluctance to convert them. Kirk sessions summoned women whose husbands had conformed roughly as often as anyone else and they were prepared to excommunicate them if they proved recalcitrant. Yet married women were protected by the patriarchal conventions that governed their society, where husbands administered the heritable property that their wives brought to a marriage. Although the estates of excommunicated persons were legally considered forfeit, Scottish authorities typically did not confiscate any of a wife's estate as long as her husband was in good standing with the kirk. Ministers recognized that a Protestant spouse was an indispensable ally in winning the conversion of a recalcitrant Catholic, though crypto-Catholics could certainly exploit this situation. Men who only grudgingly conformed to the kirk had no interest in forcing their wives to renounce a religion that they still, in secret, continued to call their own. They safeguarded their own positions by slyly inverting their patriarchal authority, complaining to the kirk that they had no

John Donald, 1981); Todd, Culture of Protestantism; Daniel MacLeod, "Servants to St. Mungo: The Church in. Sixteenth-Century Glasgow," PhD diss., (University of Guelph, 2013); Paul Goatman, "Religious Tolerance and Intolerance in Jacobean Scotland: The Case of Archibald Hegate Revisited," Innes Review 67, no. 2 (November 2016): 159-81.

${ }^{15}$ Catherine McMillan, "'Scho Refuseit Altogidder to Heir His Voce': Women and Catholic Recusancy in North East Scotland, 1560-1610," Scottish Church History 45, no. 1 (2016): 36-48.

${ }^{16}$ Ibid., 47. 
power or influence over their wives. Scottish Protestants eventually grew wise to this strategy, and in 1642 the Privy Council passed a measure that held husbands responsible for the religious proclivities of their wives. ${ }^{17}$ Presbyterian ministers expected all Scots to attend church on Sundays, and they could no longer stomach this gendered loophole.

One cannot fully grapple with the kirk's treatment of Catholic women without first appreciating Scotland's unique approach toward religious uniformity. Scottish Catholics faced enormous pressure to conform to the new order but, unlike their co-religionists in England or elsewhere in Protestant Europe, they almost never faced the possibility of state-sanctioned violence. This anomaly was well known at the time, with Catholic missionaries in Scotland candidly admitting that "the heretics extol their own clemency in not shedding blood, like our Inquisitors [do]". ${ }^{18}$ The Scottish Parliament passed a series of stringent anti-Catholic measures at the Reformation, but many of these laws had little impact on the kingdom's actual religious policy. These included the aptly titled Act Anent the Mass, which levied severe penalties on those who participated in Catholic worship. Priests and lay attendees would lose their lands and titles on the first offense, followed by banishment for the second and execution for a third. ${ }^{19}$ Such punishments, however, were seldom levied. Although a handful of Scottish

\footnotetext{
${ }^{17}$ P. Hume Brown, ed. Register of the Privy Council of Scotland, vol. 7 (Edinburgh: HM General Register House, 1906), 295.

18 "Fr. William Leslie to Fr. General, 1 September 1630," in Memoirs of Scottish Catholics During the XVIIth and XVIIIth Centuries, vol. I, ed. William Forbes-Leith (London: Longmans, Green \& Company, 1909), 78-9.

${ }^{19}$ K. M. Brown, et al. (eds), The Records of the Parliaments of Scotland to 1707 [hereafter RPS] (St Andrews, 2007-2017), A1560/8/4.
} 
Catholics were indeed imprisoned in the century after the Reformation, no Scot was ever executed for harbouring a priest. And with the sole exception of James Ogilvie, a Jesuit priest hanged in 1615, no clergyman faced the scaffold for saying mass within the kingdom. ${ }^{20}$

Scotland's reluctance to enforce these laws hardly suggests that Catholics enjoyed a kind of quasi-toleration. The Presbyterian kirk rigorously sought to achieve doctrinal uniformity in every parish, and it hoped to achieve genuine conversions from recalcitrant Catholics. While their remit did not extend very far into the Highlands, kirk sessions effectively governed religious life in the Lowlands, home to all of Scotland's major towns and burghs, and they certainly did not leave Catholics alone to contemplate reformed theology. Instead, they embarked on a sustained campaign of psychological pressure designed to wear down Catholic resistance, refusing to relent until suspected papists swore that they accepted reformed theology. If Scots informed the kirk session of any Catholics in their midst, the session would require those individuals to appear and explain their theological beliefs. Those who refused to attend could eventually be forcibly brought before them. If their beliefs ultimately proved wanting, ministers would often provide remedial instruction of varying levels of intensity. The Ellon presbytery, for instance, compelled the recusant George Gordon of Gicht to confer with his minister every Monday and Thursday, where they discussed a range of theological topics. ${ }^{21}$ And when the twenty-three year

\footnotetext{
${ }^{20}$ Scotland's treatment of its Catholic minority sharply contrasts with the punishments meted out to Catholic clergy in England, where as many as 116 clergy and 75 laymen and women had been put to death. Marie Rowlands, "English Catholics in the Reign of Elizabeth," History Review 59 (December 2007): 7-12. John Ogilvie, Scotland's sole Catholic martyr, was technically executed for treason rather than for saying mass.

${ }^{21}$ Presbytery of Ellon Minutes, 1607-1628, CH2/146/2, NRS, Edinburgh, UK.
} 
old recusant Alexander Elphinstone renounced popery in 1601, he was forced to undergo a five-month course with the fearsome preacher Andrew Melville, who promptly saw to it that Elphinstone never considered backsliding again. ${ }^{22}$

Ministers preferred to employ tactics that were deemed to rely on persuasion rather than force, even though to Catholics those tactics could seem rather forceful. Ministers were also willing to continue with measures of persuasion even when they did not appear to be having any immediate effect. The Aberdeen session advised in 1573 that "transgressors agains ye Religion...be first handillit and travellit wt gentilly, gif be ony meanis possiblie yai may be von" (be first handled and laboured with gently, if by any means possibly they may be won). ${ }^{23}$ Although Aberdeen possessed a substantial Catholic and crypto-Catholic population well into the seventeenth century, it was no outlier in adopting such a cautious approach. St. Andrews had adapted rather quickly to Protestant reforms, and the city's kirk session boasted as early as 1564 that "the face of ane perfyt reformed kyrk hes beyn seyn within this cite be the space of five yearis". ${ }^{24}$ Nevertheless, the elders shared their Aberdeen brethren's patience, proclaiming their willingness "to wyn synneris wyth quietness rather nor sevirite to repentans, evir hoping from day to day willing obedience and satisfaction". ${ }^{25}$ They readily displayed this forbearance on several occasions, even when dealing with defiant parishioners. The St. Andrews kirk session summoned the recusant David Dischington in 1568, but the recusant promptly

${ }^{22}$ William Fraser, The Elphinstone Family Book of the Lords Elphinstone, Balmerino and Coupar (Edinburgh, 1897), vol. 1, 180-1.

${ }^{23}$ St. Nicholas Kirk Session Minutes, Aberdeen, 1562-78, CH2/448/1, 25, Aberdeen Council Archives, Aberdeen, UK.

${ }^{24}$ David Hay Fleming, Register of the Minister, Elders and Deacons of the Christian Congregation of St. Andrews, 1559-1600 (Edinburgh: Scottish History Society, 1889), 203.

${ }^{25}$ Ibid., 473. 
"departit wytht fume and anger" when the elders pressed him on his religious allegiances. Rather than excommunicate him or appeal to the magistrates for his arrest, the session "being of mynd to repress his stubburnes and be al meanis possible to wyn hym" simply ordered him to appear once he had calmed down. ${ }^{26}$

The kirk's patience was far from boundless, however. Catholics eventually risked excommunication if they refused to comply, a dreadful sentence that most sought to avoid. It lurked in the background only as an absolute last resort, when resolute delinquents would be cast out of the Church of Scotland and all but their nearest kin forbidden to interact with them. Their lands and possessions were considered forfeit, and excommunicates could be imprisoned or banished at a moment's notice. A few enterprising kirk sessions went even further, levying curfews, confining excommunicates to a certain radius around their homes, and sometimes even passing ordinances designed to keep them off the streets altogether. In Glasgow, for example, the St. Mungo kirk session ordered excommunicates to "keep themselves closed within their house" until they were ready to recant their errors. ${ }^{27}$ In 1585 , the Glasgow session actually disciplined one Marion Andro for speaking with her excommunicated son, who was also rebuked for leaving his house. ${ }^{28}$ In practice, however, excommunication added yet another layer of intrusive preaching and proselytization, one much more onerous than before. Ministers were perfectly aware that excommunicates would attempt to contact friends and associates, and rather than ban such interactions outright, many kirk sessions sought to turn them into yet another opportunity for evangelization. Protestants who wished to transact business with excommunicates had to

${ }^{26}$ Ibid., 297.

${ }^{27}$ St. Mungo Kirk Session Minutes, Glasgow, 1583-1593, CH2/550/1, 213, Glasgow City Archives, Glasgow, UK.

${ }^{28}$ Ibid., 69. 
receive permission from their kirk sessions in advance, and they were required to set aside a period of time to discuss the truth of the Protestant religion. Indeed, the Aberdeen kirk session expressly forbade any interaction "except it be knawn and prowin for the reconciliatioun and wynning of tham to God". ${ }^{29}$ Any potential meeting was closely regulated by the kirk, which took steps to ensure that religious discussions actually took place. In 1584, for instance, the Protestant James Blackwood applied to the Stirling presbytery for permission to visit his excommunicated brother's home, which Blackwood claimed offered the perfect opportunity to persuade his brother "to renounce that damnablle religioun of papistrie and imbrece the trew lycht of the evangel". ${ }^{30}$ The presbytery granted Blackwood's request on the condition "that he mak adverteisment of befoir to ane of the ministeris in Dunblane," which further also required him to provide a full report on what transpired at their meeting. Moreover, the presbytery granted an additional "lycence to the said James to pas with ane minister and ane elder conjunctlie to the presens of the said excommunicate, at sic tymis as thai thocht meit to confer with him anent the religioun". ${ }^{31}$ The minister and elder were to act as chaperones, guiding the discussion to ensure that it met with the kirk's rigorous standards. The Blackwood brothers thus managed to conduct their business without incurring the wrath of the kirk, but it came at a price.

Scottish excommunicates routinely applied for these licenses, accepting humiliating restrictions on their movement in exchange for the freedom to move at all. They consented to the same regimen of preaching and conferences that they had previously defied, and the experience unsurprisingly led some excommunicates to consider conforming to the kirk. Those

${ }^{29}$ Stuart, Aberdeen Selections, 35.

${ }^{30}$ James Kirk, ed., Stirling Presbytery Records, 1581-1587 (Edinburgh:

Scottish History Society, 1981), 219.

${ }^{31}$ Ibid., 219. 
who refused to participate were eventually condemned as incorrigible, leaving room for the state to confiscate their assets and imprison them. The kirk may have been slow to recommend this course, but confiscation and imprisonment occurred often enough for Catholics to fear it.

Scottish Catholics therefore had little choice but to deal with an intrusive, overbearing kirk. After observing the activities of kirk sessions in Edinburgh, the priest William Crichton complained that in Scotland "the power of the heretical ministers is so great that they can compel every one to subscribe their false confession of faith, attend their sermons, and take the profane supper of the Calvinist rite". He lamented that "the Catholics are so unnerved by this severity that very few of them remain firm," and he feared that their numbers would dwindle until they finally faded away. ${ }^{32}$ Yet the kirk's patient "travelling" with those it hoped to convert offered an unintended benefit to Catholics who were anxious not to abandon their faith. They needed only to pretend interest in the reformed religion, since the kirk would almost immediately halt excommunication proceedings if there was even the slightest chance of their conversion. Ministers continued to confer with accused Catholics even when they suspected that they were merely buying time and had no intention of actually converting to the Protestant religion. The Synod of Fife admitted in 1612 that George Gordon of Gicht's "making some shew of ane desire to be resolved in the headis of religion hes bein for no vther end but to illude the Kirk, and slew the further executioune of the lawes against him" (making some show of a desire to be resolved in the points of religion has been for no other end than to elude the kirk and slow the further execution

\footnotetext{
32 "Fr. Crichton to Fr. Claud Aquaviva, 30 September 1605," in Narratives of Scottish Catholics Under Mary Stuart and James VI, ed. William Forbes-Leith (Edinburgh: William Paterson, 1885), 285.
} 
of the laws against him). ${ }^{33}$ Yet the synod was so committed to winning Gicht's conversion, despite his almost transparent disinterest in the reformed religion, that it dropped its objections as soon as he offered, once again, to confer with a minister and consider the Confession of Faith. ${ }^{34}$

Catholics who chose this course still had to contend with frequent, and often tense, interrogations before officious kirk sessions. Unsurprisingly, more than a few suspected Catholics were not quite as prepared as their interrogators expected. The Aberdeen recusant Robert Lang unfortunately did not have an answer when his kirk session asked him "quhat poynt of the confessioun of Fayth he doubtis upon, and to tell his scruples" (what point of the Confession of Faith he has doubts about, and to tell his scruples).$^{35}$ The session was not impressed, and it ordered him to study for several more weeks before he appeared before them again. Catholics of both sexes often endured this maelstrom together, for the kirk routinely expected women, as well as men, to demonstrate their mastery of Calvinist doctrine. The Perth kirk session refused to sanction the marriage of one couple in 1593 "because both the one and the other, the man and the woman, are ignorant of their Belief"' and lacked a proper understanding of the Apostles Creed. Its elders offered further instruction, but they would not allow the marriage to go ahead "unto the time that they learn to give a confession of their faith". 36 The Culross kirk session even refused to allow one woman, Margaret Dawson, to repent for committing fornication until she better understood the scriptures, finding her "altogether ignorant of god and His commandments" and wholly "unworthy to enter the place of

${ }^{33}$ Ecclesiastical Records: Selections from the Minutes of the Synod of Fife, 1611-87 (Edinburgh: Abbotsford Club, 1837), 55.

${ }^{34}$ Ibid., 71 .

${ }^{35}$ Stuart, Aberdeen Selections, 89.

${ }^{36}$ St. John's Kirk Session Minutes, Perth, 1587-1596, CH2/521/2, 117, NRS, Edinburgh, UK. 
publick repentance til [she offered] greater evidence of hir knowledge". ${ }^{37}$

The kirk closely monitored those Scots whom they forced to undergo remedial education. The Perth kirk session thought that the recusant Bessie Glass might come to a better understanding of the Protestant faith by watching others undergo their own examinations, ordering her to "be every day an hour before noon hearing the examination public in the kirk in the rudiments of religion, and so to learn". ${ }^{38}$ When the Rhynie minister George Chalmer conferred with the Catholic Lady Strabane in the autumn of 1643, the presbytery of Strathbogie ordered him to "watch her hous as narrowlie as he could," hoping to ensure that she received no underground priests, Jesuits, or "any excommunicate persones quhatsomeuer" in the meantime. ${ }^{39}$ These women risked excommunication if they failed to comply, and if they were single, widowed, or married to an excommunicate themselves, potentially faced all of its attendant consequences, up to and including their own imprisonment. Yet if they were married to a Protestant, or to a crypto-Catholic who feigned just enough interest in Calvinism, they risked substantially less by defying the kirk. Ministers were determined to win a married woman's conversion, but their threats of excommunication carried less weight when the kirk could take no further measures against her. The experience of Isabel Wood, the recusant wife of George Gordon of Gicht, neatly encapsulates the advantage of having a husband in (relatively) good standing with the kirk.

As we have seen, George Gordon of Gicht endured long discussions with his minister on the merits of Calvinist

\footnotetext{
${ }^{37}$ Culross Kirk Session Minutes, 1646-1657, CH2/77/2, 81, NRS, Edinburgh, UK.

${ }^{38}$ St. John's Kirk Session Minutes, Perth, 1577-1586, CH2/521/1, 74, NRS, Edinburgh, UK.

${ }^{39}$ Presbytery of Strathbogie Minutes, 1631-1654, CH2/342/2, 44, NRS, Edinburgh, UK.
} 
theology without ever formally converting to the Protestant faith. His wife, however, flatly refused either to meet with the minister or to appear before the presbytery in Ellon, a move that unsurprisingly led to her excommunication. Isabel Wood was prohibited from interacting with any Protestant Scots thereafter, with the exception of her husband, who pointedly reminded the kirk that he would refrain from meeting with any excommunicate, his "bed-fellow being exceptit". ${ }^{40}$ Nevertheless, Wood's excommunication was not as debilitating as it might have initially appeared. She almost certainly would have faced some social isolation, but neighbours who were prepared to overlook her Catholicism could still meet with her under the pretense of visiting her husband. Although she was forbidden from conducting any business on her own, she could accompany her husband on visits to local markets and rely on him to purchase any needed goods. Wood therefore had less of an incentive to submit to the grueling licensing system faced by most excommunicates, and she risked none of the civil penalties for refusing to do so. The Ellon presbytery repeatedly asked Gicht to bring about his wife's conversion, but the troublesome laird responded by implying that he had little control over the religious affairs of his household. When the couple secretly baptized their newborn child into the Catholic faith, for instance, Gicht strategically shifted the blame onto his wife, informing the presbyters that "whether his bairnes were baptized or not, or be whom he knew not. To that his wyffe alone wes privie". ${ }^{41}$

Gicht surely knew that his child had been baptized into the Catholic faith, and his claim that Wood had arranged it without his knowledge was no more than a transparent attempt to escape kirk censure. Wood was already excommunicated, so there was little the kirk could do to discipline her for this

${ }^{40}$ Stuart, Aberdeen Selections, 180.

${ }^{41}$ Presbytery of Ellon Minutes, 1597-1607, CH2/146/1, 9-10, NRS, Edinburgh, UK. 
transgression. Yet if Gicht shouldered the blame himself, he risked his own excommunication and would expose his family to the full might of the Scottish church and state. This inversion of the patriarchal order was often, though not always, carefully crafted to enable husbands to avoid such an eventuality, thus preserving their wife's Catholicism as well as the husband's own tenuous relationship with the kirk.

Some conforming husbands took this strategy even further, arguing that they had no control over their wives whatsoever. The Essilmont crypto-Catholic John Cheyne told the presbytery of Ellon that he was powerless to prevent his wife from seeing a priest, and therefore could not be expected to stop her. Cheyne's wife, a formidable woman named Elspeth Garioch, kept a tavern in Aberdeenshire that doubled as a meeting place for underground priests. ${ }^{42}$ She ignored repeated summons to appear for papistry, and would not even pretend to be interested in the reformed religion. Her minister, John Mercer, asked his congregation to pray for her conversion, but he eventually had little choice but to excommunicate her, a sentence he pronounced in May 1608. ${ }^{43}$

The Ellon presbytery sought to emphasize the severe disabilities that Garioch would face as an excommunicate, sternly condemning her as a woman worthy of total exclusion from the kirk. Her minister justified this fearsome sentence, warning his flock that she was nothing but "ane rotten member of the Misticall body of Christ, noysum and hurtfull to the congregatioun, and behoveit to be cut off as ane Rotten member". ${ }^{44}$ The presbyters hoped to limit her interaction with other Scots, but they were hamstrung by her husband's occasional conformity. As long as John Cheyne avoided excommunication himself, the authorities could not confiscate

${ }^{42}$ Ibid., 106.

${ }^{43}$ Presbytery of Ellon Minutes, 1607-1628, CH2/146/2, 19, NRS, Edinburgh, UK.

${ }^{44}$ Ibid., 19. 
any of her property, nor could they do much to encourage her to emigrate. They were unable to requisition the tavern she kept as a meeting place for the Catholic underground, even though they warned Protestants against patronizing it. Moreover, the presbytery made several unsuccessful attempts to force Cheyne to exert tighter control over his wife, both before and after her excommunication. Cheyne swore an oath not to invite Jesuits or other priests into his home, but he claimed that he could not prevent his wife from doing so. Indeed, Cheyne pleaded that "she would do nothing for him in that point," averring that he could not be held responsible if priests visited at her invitation. ${ }^{45}$ Cheyne was therefore willing to appear to be failing in his patriarchal duties in order to shelter his wife from prosecution for her nonconformity. He further declared that there was no chance that he could ever convince her to attend church or obey the presbytery, noting that she "wald not be [made] be him to be obedient to the voce of the kirk". ${ }^{46}$

Cheyne's minister eventually came to believe that it was Elspeth Garioch, and not her husband, who determined the religious affiliations of their household. Indeed, when Mercer finally decided to move against him, Cheyne went so far as to claim that "he had na hope of his [settled] conformity since his wyf was excommunicated," a statement that awkwardly elides the sixteen years that had elapsed since her exclusion from the kirk. ${ }^{47}$ Mercer could have excommunicated Cheyne quite a bit earlier if he truly had no hope of his conversion, but the minister's claim that Garioch ruled their household is not so easy to dismiss. Cheyne might indeed have been telling the truth when he argued that his wife "would do nothing for him" in religious matters. Some early modern Scottish women really did shape the religious allegiances of their families, over and above their husband's objections. The Aberdeenshire apostate

${ }^{45}$ Ibid., 15.

${ }^{46}$ Ibid.

${ }^{47}$ Ibid., 187. 
Thomas Grant, for instance, appeared voluntarily before the Strathbogie presbytery in June 1654, craving forgiveness for his conversion to Catholicism. He claimed that his wife and her family had led him astray, explaining that "that through evill companie, example, and allurements of his father-in-law, wife, and preists, he hade bein drawen to scruples". Happily, however, "now they wer removed," and he promised "that he sould continue constant in the true religion". 48 Grant's voluntary appearance lends credibility to his claims, and there is no reason to doubt the strong influence of his wife and her family.

$* * *$

While married women enjoyed some protection from the worst effects of excommunication, single or widowed Catholics were exposed to the full might of the Scottish kirk. This was true even of elite Catholics, whom kirk sessions were determined to bring to heel. The General Assembly insisted on discipline "without exception of persons," and as Margo Todd has noted, "there were enough cases of the well born failing to buy their way out to suggest that this message was the overriding one". 49 Marion Boyd, countess of Abercorn, was among those who failed to overawe the local ministry. The presbytery of Paisley summoned her on multiple occasions after her husband's death in 1618, exhorting her to abandon her erroneous past and embrace the Gospel. Abercorn made a few halfhearted gestures toward conformity, offering at one point to "resort to the hearing of god's Word preached" and agreeing to meet privately with several presbyters. ${ }^{50}$ Unfortunately, the intrepid

\footnotetext{
${ }^{48}$ John Stuart, ed., Extracts from the Presbytery Book of Strathbogie, 1630-1654 (Aberdeen: Spalding Club, 1843), 251.

${ }^{49}$ Todd, Culture of Protestantism, 176.

${ }^{50}$ Presbytery of Paisley Minutes, 1626-1647, CH2/294/2, 21, NRS, Edinburgh, UK
} 
countess did not get along well with the parish minister, Robert Boyd, who confessed to his wife that the countess was "so coldly disposed toward me that I expect no friendship or courtesy on her part". ${ }^{51}$ The presbytery might have continued to patiently reason with her, but a rash announcement from her son, who had inherited the earldom at his father's death, soon laid bare the family's religious allegiances. The earl of Abercorn announced his conversion to Catholicism in April 1627, shocking Protestant opinion throughout the entire region. The presbytery of Paisley fumed that the earl had unmasked himself as an apostate, a man who "doth openly avowe himself a papist, and verie contemptuously despiseth the word of god, preached publickly or read privately...to the great dishonor and offense of God and of all truly religious hearted Christians". 52 The countess of Abercorn might have admired her son's resolution to remain steadfast in his Catholic faith, but she was perhaps less enamoured with his subsequent decision to depart for self-imposed exile on the continent, which undercut her support network. The countess now enjoyed virtually no legal protection from a vengeful kirk, but she still would not be moved to accept the Protestant religion. Excommunicated in May 1628, she was taken to Edinburgh and imprisoned in the city's fearsome Tolbooth. Her aristocratic upbringing scarcely prepared her for life in a dank cell, where she was soon overcome with "many heavy diseases," and a "daily decay and weakness in her person". ${ }^{53}$ Her health grew so pitiful that she was eventually released on compassionate grounds, on the condition that she confer with a minister and refuse any contact

51 "Robert Boyd to Marion Boyd, 1 February 1626"; Wodrow Fol. Quatro $\mathrm{xx}, \mathrm{NLS}$, Edinburgh, UK.

52 Presbytery of Paisley Minutes, 1626-1647, CH2/294/2, 20, NRS, Edinburgh, UK.

${ }^{53}$ P. Hume Brown, ed. Register of the Privy Council of Scotland, vol. 3 (Edinburgh: HM General Register House, 1906), 253. 
with priests or Jesuits. She returned to Paisley, broken in body and spirit, where she died on 26 August 1632.

The countess of Abercorn's husband had occasionally conformed to the church of Scotland, and she would likely have never met this unfortunate fate had he remained alive. Nevertheless, married women were safe from the kirk only if their husbands decided to play along. Spouses of excommunicated women needed to remain in good standing with the kirk, conforming often enough to avoid their own excommunications for papistry. Although Catholic missionaries allowed their flocks to attend their parish kirks without threatening them with the loss of their immortal souls, some Catholics struggled with their decisions to feign outward conformity. ${ }^{54}$ The Aberdeen recusant George Gordon of Gicht once grew so tired of his dealings with the presbytery that he offered to die as a martyr, informing the bemused presbyters that "giff it sall pleis Majestie and your wisdoms of the Kirk of Scotland sa to tack my bluid for my professioun, quhilk is Catholick Romane, I will maist willinglie offere it for the same". ${ }^{55}$ The Aberdeen presbytery did not take the bait, and Gicht eventually thought better of his challenge, agreeing shortly thereafter to confer with a minister. He knew that his excommunication, let alone the crown of martyrdom, would "ondoubtitlie...prejudge my wardlie estait" (undoubtedly... prejudice my worldly estate) and leave his already excommunicated wife with nothing. ${ }^{56}$ Gicht never seriously considered converting to the Protestant religion, though he made a grand show of feigning enough interest to avoid losing his family's lands and possessions.

\footnotetext{
${ }^{54}$ Some crypto-Catholics attended communion but assuaged their consciences by dropping the host. Others passed each other Catholic devotional books during the sermon. See, for example, Minutes of the Synod of Fife, 48.

${ }^{55}$ Stuart, Aberdeen Selections, 180.

${ }^{56}$ Ibid.
} 
Gicht's wife, Isabel Wood, managed to sustain her nonconformity in relative peace, and she died without ever accepting the Protestant faith. These protections, however, would not last very far into the next generation, as the kirk's patience with Catholic women in mixed marriages was wearing thin by the late 1630s. In the wake of the National Covenant, Scottish Protestants renewed their efforts to purge the nation of any semblance of popery. Half-measures would not suffice, and anxious ministers could no longer stand aside and wait for Protestant husbands to bring around their recalcitrant wives. Scottish authorities especially feared that excommunicated women might entertain priests in their homes, where they could easily "corrupt the children and servants of the hous in their religion". ${ }^{57}$ The Privy Council, which by 1642 included Covenanter stalwarts like the earl of Loudon and the marquess of Argyll, sternly condemned the mixed marriage loophole in Scottish religious policy. Although "the resset of Jesuits, seminarie and messe priests has been oft prohibit and discharged," the Privy Council lamented that "the execution of the saids lawis have been illudit be the wyffis of persones repute and esteemed to be sound in religion, who pretending misknawledge of the actions of their wyffes in thir cases, thinke to liberat thamselfes of the danger of the resset as if they were not to answer for their wyffes doings". ${ }^{58}$ They sought to quash this deceitful excuse by making husbands formally responsible for their wives' behaviour, forthrightly declaring "that the husband sall be answerable to his Majesties Counsel and Justice of the kingdome that his wyffe, being a profest papist or under processe for poperie, sall not resset, supplie nor entercommon with Jesuits nor priests, and that he nor she sall not be served be papists, and that nane sall be admitted to their service bot suche as have a testimonial frome the minister

${ }^{57}$ Hume Brown, ed. Register of the Privy Council, vol. 7, 295.

${ }^{58}$ Ibid., 296. 
quhair they duell of the soundnesse of their religion". ${ }^{59}$ Married women were still exempt from any property confiscations, but their conforming husbands would now be held accountable if their wives decided to visit a priest. These men could no longer plead, as Gordon of Gicht did earlier in the century, that their wives kept them in the dark about secret baptisms and encounters with priests.

Protestant men now faced significant consequences for participating in mixed marriages. In 1649, for instance, the presbytery of Peebles levied a $£ 5000$ fine on the Protestant John Stewart, Lord Linton, for marrying the Catholic Henrietta Gordon, imprisoning them both and excommunicating the presiding minister. ${ }^{60}$ This newfound impatience led many families to think twice before engaging in open defiance against the kirk. The crypto-Catholic William Douglas, marquess of Douglas, once insisted to the presbytery of Lanark that although he was "content to admit conference for himself," he would "not be answerable for his Lady, nor cause his dochter to goe to the church against her will". He argued that his wife, Mary Gordon, and daughter could decide for themselves whether they wished to conform or not, adding that while he would not force either woman to go, "for his pairt [he] will not hinder hir". ${ }^{61}$ The marquess sang a rather different tune by the early 1640s, when he could longer plead disinterest in the conformity of his household. The presbytery of Lanark had appointed the elders Alexander and William Somerville to discuss Protestant theology with the truculent marquess, and they reported that not only had he "beene at churche himselfe,"

${ }^{59} \mathrm{Ibid}$.

${ }^{60}$ Presbytery of Peebles Minutes, 1649-1688, CH2/295/4, 17, NRS, Edinburgh, UK; Robert Chalmers, Domestic Annals of Scotland from the Reformation to the Revolution (Edinburgh: W. \& R. Chambers, 1874), 189.

${ }^{61}$ Selections from the Registers of the Presbytery of Lanark (Edinburgh: Abbotsford Club, 1839), 10. 
but also "undertakes for himselfe, his ladie, and children, that they shall be constant and ordinar hearers of the worde". ${ }^{62}$ Although the presbyters recorded that they had "gladlie heard" the news, nobody in the Douglas household had actually experienced a Damascene conversion. ${ }^{63}$ All parties continued to drag their feet, hoping, like so many other Catholics throughout their early modern period, to delay their conversion for as long as they possibly could. Nevertheless, Lady Douglas had to play the same game as her husband, scrupulously avoiding her own excommunication from the kirk, since her husband's conformity would no longer protect them both.

Unsurprisingly, the presbytery of Lanark struggled for quite a long time to win her conversion. The presbyters sometimes grew rather frustrated with her progress, observing in July 1644 that she "doethe still continue obstinate, notwithstanding the pains the presbyterie hath taken verie frequentlie for her informatione and conversion". ${ }^{64}$ The minister John Wilson publicly admonished her for resisting the kirk, while threatening to begin proceedings that might end with her excommunication. Yet the presbytery promptly set aside these efforts several weeks later, when "shee came with her children and the rest of the famillie obedientlie to church". The marquess of Douglas personally vouched for his wife once again, promising that "she shalbe ane ordinar hearer of the time to come". ${ }^{65}$ The presbyters accepted this excuse, viewing her conversion as their ultimate, overriding goal. Indeed, when Lady Douglas finally agreed to sign the Confession of Faith and the Solemn League and Covenant, the elders Robert Birnie and Richard Inglis warned her not to submit unless she truly accepted the reformed religion reminding her "how fearfull a sinne it was, to sweare with equivocation or mentall

${ }^{62}$ Ibid., 33.

${ }^{63}$ Ibid.

${ }^{64}$ Ibid., 35 .

${ }^{65}$ Ibid., 36. 
reservation". They added that "if shee desired any further satisfaction, or had any scruples or doubts, that shee desired further resolution in, that they were readie to wait vpon her La[dyship]". ${ }^{66}$ Lady Douglas, at last, signed the documents and swore to uphold the Protestant faith. She had endured years of intrusive proselytization alongside her husband, but at least she avoided excommunication and the penalties that might have accompanied it.

The kirk's relentless pursuit of Catholic women forced at least one conforming husband to perform a near-Herculean task. The Paisley presbytery threatened the Protestant John Wallace with grave consequences if he refused to bring his recusant wife to church, and because she had continually pleaded illness as the reason for her non-appearance, the presbytery explicitly demanded that Wallace bring her there on her bed. ${ }^{67}$ Wallace's wife, Margaret Hamilton, had renounced her attachment to Catholicism the previous year, "first of one point, then on another," swearing a rather detailed oath that she rejected "all the points of poperie". ${ }^{68}$ The presbyters put little stock in her sincerity, remembering that she had once sought to demonstrate her Calvinist leanings by asking her minister for a copy of the National Covenant, which she ostentatiously "read over and over again". Hamilton did nothing to assuage their fears when she stayed home from church the following Sunday, informing the increasingly impatient presbytery that she was far too ill to get out of bed. The presbytery eventually dispatched ministers to read the Gospel at her bedside, but they soon suspected that her illness was a sham. ${ }^{69}$ It was not the first time that she had used such an excuse to explain her absence, though she was no more successful now than she had been

${ }^{66}$ Ibid., 81

${ }^{67}$ Presbytery of Paisley Minutes, 1626-1647, CH2/294/2, 275, NRS, Edinburgh, UK.

${ }^{68}$ Ibid., 234.

${ }^{69}$ Ibid., 250. 
before. The minister Henry Calvert had bluntly asked her during a previous occasion "whether it were inability of her body onlie that restrains her from coming to God's house for hearing His Word or if she [had] scruples of conscience anent the religion professed in the kirk and kingdom". ${ }^{70}$ Hamilton pleaded that she truly was too ill to attend church, and sent an excuse signed by the physician James Fleming, who testified "on his conscience that she is unable to travel either on foot or horse" ${ }^{71}$ She begged to be left alone, repeatedly insisting that she would dutifully attend church as soon as her health would permit.

Hamilton's ordeal, however, was far from over. The presbyters doubted the veracity of Fleming's report, and their suspicious were confirmed when he failed to produce another one several months later. ${ }^{72}$ They rebuked her husband, John Wallace, coldly demanding that he carry "her to Paisley by next Presbytery day, either by land or by water". ${ }^{73}$ They ordered Wallace to bring her before them on her bed, which he carried with help from several attendants on 2 June $1647 .{ }^{74}$ Hamilton seems to have conformed thereafter, and her long, humiliating spectacle was finally at an end.

John Wallace had a clear interest in satisfying the kirk's demands. By 1647, married women no longer possessed the protections they once enjoyed, and Wallace himself could be held accountable if his wife ever decided to worship as a Catholic. Unlike Elspeth Garioch, Isabel Wood, and a host of other Catholic women earlier in the seventeenth century, Margaret Hamilton could not take shelter behind her husband's outward conformity. Yet the persistence of this gendered loophole into the Covenanter era, despite the kirk's relentless

\footnotetext{
${ }^{70}$ Ibid., 192.

${ }^{71}$ Ibid., 250.

${ }^{72}$ Ibid., 253.

${ }^{73}$ Ibid., 255.

${ }^{74}$ Ibid., 277.
} 
pursuit of religious uniformity after the Reformation, offers an intriguing window into the roles of gender and faith in early modern Scotland. It demonstrates the ways in which Scottish women sought to use patriarchal assumptions to their advantage, and how more than a few men readily undercut them in order to ensure the safety of their families. Mixed marriage couples in Scotland lacked the de facto toleration afforded their counterparts in England and the Netherlands, forcing both men and women to respond creatively to an overbearing ministry. Kirk sessions and presbyteries did not shrink from summoning Catholic women, and ministers believed that with sufficient instruction and edification, they could be persuaded to abandon their old beliefs. Some women, however, managed to resist those efforts without suffering the requisite penalties for doing so. Their marriages protected them from the worst effects of excommunication, and from the full might of an intrusive, Presbyterian kirk. 